ПЛ-1

\title{
ТЕНДЕНЦИИ РАЗВИТИЯ АНАЛИТИЧЕСКОЙ ХИМИИ
}

Золотов Ю.А.

Институт общей и неорганической химии им. Н.С. Курчатова РАН, Москва, Россия

zolotov@igic.ras.ru

DOI: 10.26902/ASFE-11_02

Рассмотрены потребности практики во внелабораторном, вещественном, дистанционном, прямом (без разложения и пробоподготовки), непрерывном локальном анализе. Оценены практические потребности в части анализа важнейших объектов и обнаружения (определения) ряда аналитов. Одновременно освещаются возможности аналитики отвечать на эти вызовы практики. Уделено внимание потенциалам развития основных методов анализа, тем проблемам, которые следовало бы решить при создании и совершенствовании методов. Кратко анализируется положение в некоторых общих направлениях развития аналитики: автоматизация анализа, использование хемометрики, наноаналитика, микрофлюидика, обеспечение качества анализа, «зеленая» аналитическая химия. 